\section{Atipical renal cyst mimicking renal cell carcinoma: Case report}

Natasa Rakonjac, Nenad Janeski, Svetlana Kocic, Aleksandra Cvijovic, Jovana Latov Besic,Vladimir Cotric, Aleksandar Mandaric, Mirko Vasilski Department of Radiology, Clinical Hospital Center Zemun, Belgrade, Serbia

\section{Abstract}

Kidney atypical cystsclassified as Bosniak III or IV are suspicious of malignancy lesions. It is difficult in some cases to establish a right diagnosis based on radiological examinations and suggest appropriate therapeutic approach. A case of complicated hemorrhagic renal cyst in a 73 -years-old men is reported. The patient was admitted to our hospital for further evaluation of non specific abdominal and back pain and chronic urinary infections. Sonography showed a bilateral large cyst some of them with dense content. CT and MRI pointed to signs of malignancy in one cyst of left kidney, CT revealed Bosniak II F but MRI revealed suspicious malignant lesion. The presence of a malignant tumor in the cyst wall was suspected and nephrectomy was performed.Pathohistological examination showed evidence of inflamedhemorrhagic renal cystwithout malignancy. Atypical cysts can match a complicated cyst (infection, bleeding) or a cystic tumor. Radiological examination is often not enough for a clear differentiation false negative biopsy results in this group are commonand it may be necessary to perform a surgical treatment for an accurate diagnosis.

Ključne reči: kidney, malignant cyst, atypical cyst, cystic renal cell carcinoma, nephrectomy.

\section{Atipična renalna cista koja imitira bubrežni karcinom: prikaz slučaja}

Natasa Rakonjac, Nenad Janeski, Vladimir Cotric, Aleksandra Cvijovic, Jovana Latov Besic, Mirjana Tubic, Svetlana Kocic, Vuk Andrejevic

Department of Radiology, Clinical Hospital Center Zemun, Belgrade, Serbia

\section{Apstrakt}

Atipične ciste bubrega klasifikovane kaoBosniak III ili IV sususpektne na malignitet ali je u nekimslučajevima teško uspostaviti pravu dijagnozu uprkos savremenim radiološkim metodama i predložiti odgovarajući terapijski pristup. Evaluiramo slučaj komplikovane hemoragične bubrežne ciste kod 73 -godina starog pacijenta. Pacijent je primljen u našu bolnicu na dalju evaluaciju zbog nespecifičnih bolova u leđima i trbuhu i zbog hroničnih urinarnih infekcija. Ultrazvukom su verifikovane bilateralne ciste bubrega od kojih neke sa gustim sadržajem. Nakon CT pregleda jedna od tih cista je klasifikovana kao Bosniak II F, zbog diskretne opacifikacije zida ciste u jednom segmentu, dok je MR nalaz ukazao na suspektnu malignu leziju, pri čemu je opisana restrikcija difuzije intraluminalno, što ukazuje na prisustvo solidnog dela, te je pacijent nefrektomisan. Patohistološki pregled je verifikovao inflamiranu hemoragičnu cistu bez prisustva malignih ćelija. Atipična cista bubrega može odgovarati komplikovanoj cisti sa infekcijom ili krvarenjem, ali takođe i cističnom tumoru. Radiološki pregled često nije dovoljan za jasnu diferencijaciju. Lažno negativne biopsije kod cističnih promena su vrlo izvesne i često je neophodno izvršiti hiruršku intervenciju za preciznu dijagnozu.

Key words: bubreg, maligna cista, atipična cista, nefrektomija.

\title{
Uvod
}

With the disseminated use of imaging methods for the investigation of abdominal diseases, the identification of incidental findings whose management is not always easy or consensual has become increasingly common. Complex renal cysts are fully representative of such a situation ${ }^{1}$.

The Bosniak classification of cystic renal masses is well established and widely used ${ }^{2}$.

According to the current classification from 2005.lesions in category I correspond to simple cysts without septa or vegetations, with thin and smooth walls, and no contrast enhancement after the administration of intravenous contrast agents. Category II includes cysts with thin septations, minimally thick walls and fine parietal calcifications, and no contrast enhancement after intravenous contrast agent injection. Homogeneous 
hyperdense cysts $\leq 3.0 \mathrm{~cm}$ are included in this category. Lesions with irregular and/or thick septa, with course calcifications, and clear enhancement after intravenous contrast injection are described as category III. Category IV is reserved for lesions with septa or walls with well-defined solid components that demonstrate contrast-enhancement after intravenous contrast injection. (Figure 1.). Category II-F corresponds to indeterminate lesions with findings which, although not sufficient to indicate surgical exploration, suggest a slight risk of malignancy ${ }^{3,4}$ (Figure 2.)
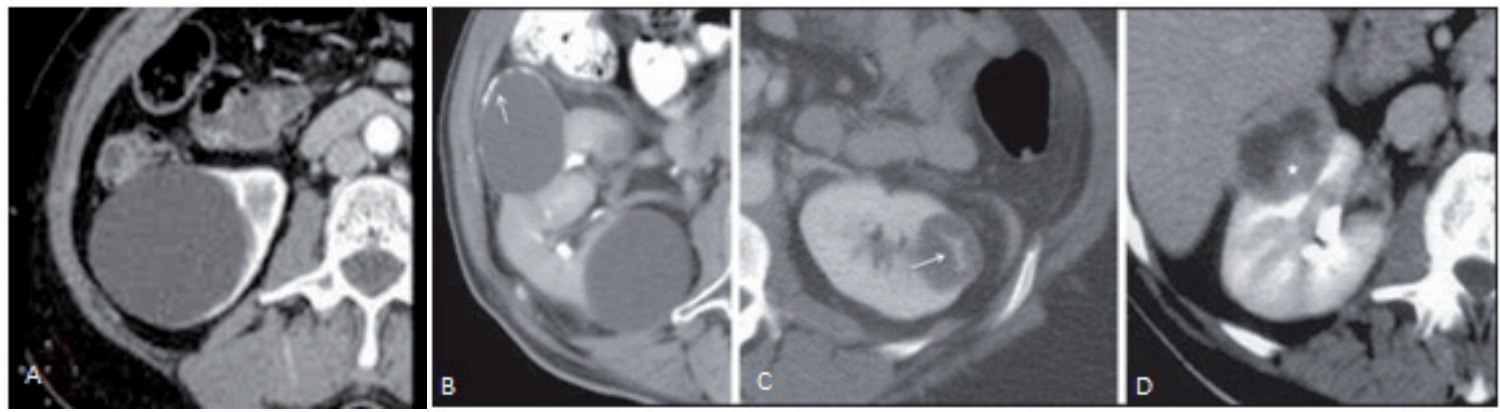

Figure 1. Bosniak classification A. cat. I, B cat II, C cat III and D cat IV

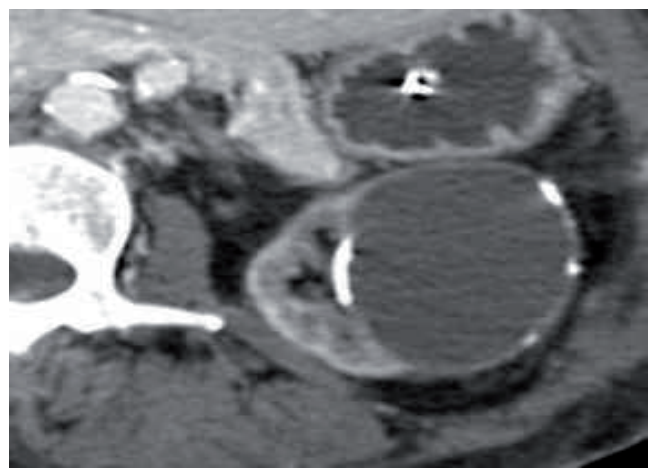

Figure 2. Bosniak Cat IIF cyst. Cyst with uniform, mild wall thickening and short, interrupted calcifications. Internally, the lesion was homogeneou

\section{Case report}

We are going to present 73-year old male patient whore ferred to our hospital with symptoms of mild pain and feeling heaviness below left rib arch and left flank, for a long time intermittently and now more frequently. In the history of disease patient noted recurrent urinary infections. No hematuria noted, blood pressure was elevated, laboratory investigations was normal. Initial ultrasound examination revealed the existence of several simply cysts on the right kidney with diameter up to 50, also calcification was seen in the wall of one interpolar cyst. On the left kidney a few small cysts with dense content was seen, as well as two larger, one on the lower pole diameter $30 \mathrm{~mm}$ and one on the upper pole diameter $60 \mathrm{~mm}$ with normal thickened but with slightly hiperehoic wall. Due to cystic changes dominant on the left kidney CT examination was performed. CT revealed that parenchyma of both kidneys is preserved thickness; there is no hydronephrosis or calculiin collection system.

On the right kidney, there were several simple cortical cysts largest in the lower pole diameter $55 \mathrm{mmposterior}$ also on the lower pole was seen cyst diameter $17 \mathrm{~mm}$ with discreetly thick wall, with nocontrast enhancement and fine linear calcification - right kidney Bosniak II (Figure 3.)

On the left kidney, there were several cysts that are hyperdense in the native phase, in postcontrast series without intraluminal and wall opacification and looked like hemorrhagic cysts or cysts with mucinous content 
/intraluminal HU 50-70/, on the left kidney were cyst $34 \times 33 \times 35 \mathrm{~mm}$ arising from lower pole with denser content and partially thickened but smooth wall which observed nonmeasurable enhancement. The MDCT findings were suggestive of Bosniak Type IIFlesion (Figure 4.).

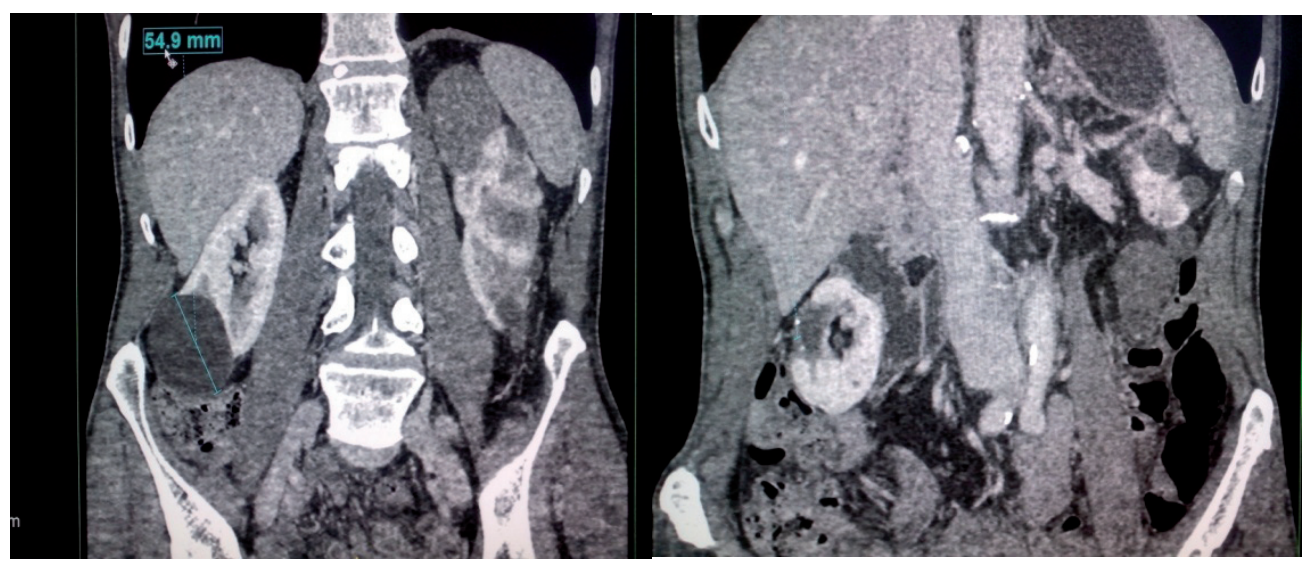

Figure 3. Rightlower pole kidney cysts Bosniak I and posteriorly Bosniak IIwith discreetly thick wall, with no contrast enhancement and fine linear calcification

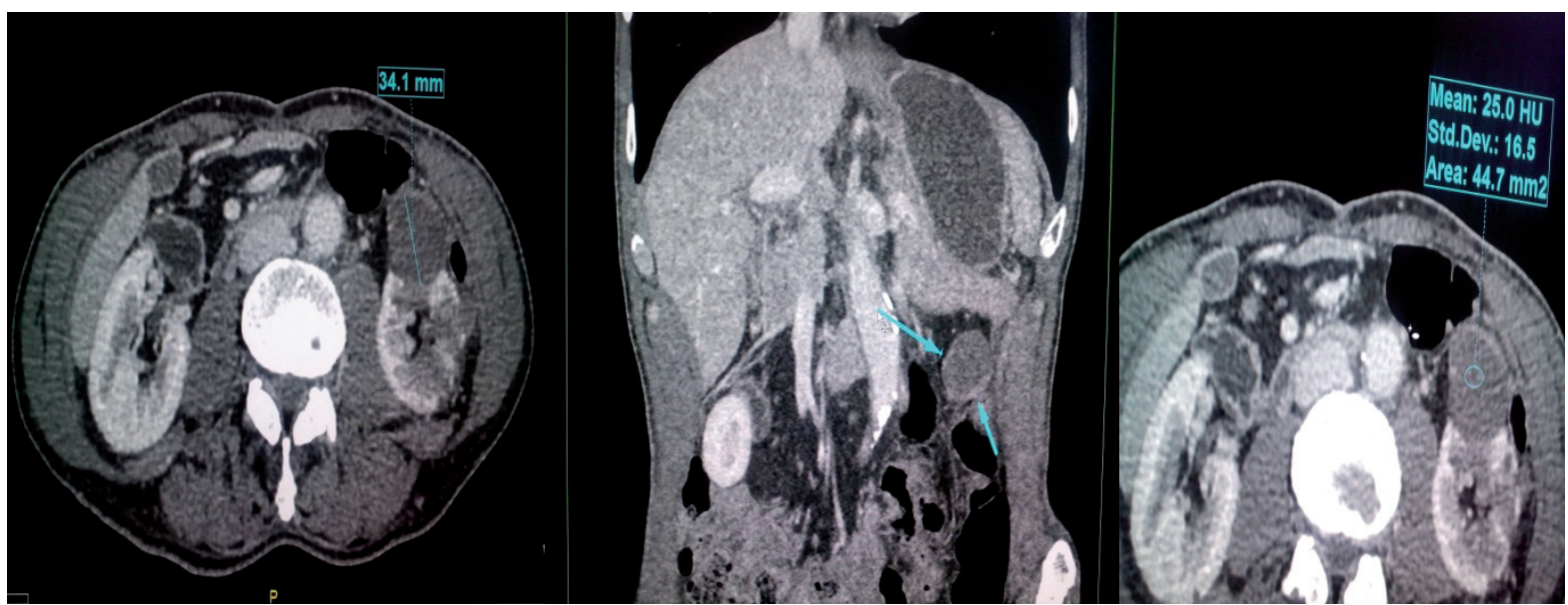

Figure 4. Left kidney cyst $34 \times 33 \times 35 \mathrm{~mm}$ arising from lower pole with denser content and partially thickened but smooth wall which observed measurable enhancement.

No retroperitoneal or peritoneal lymphadenopathy was seen.CT revealed degenerative changes on the lumbosacral spine with the rest normal findings in abomen and pelvis. Due to precisely characterization of cyst Bosniak IIFin the lower pole of left kidney MRI of abdomen and pelvis was recommended for farther evaluations.

MRI revealed hyperintensity at T1, hypointensity at T2 with fat suppression. Pre-contrast and post-contrast T1 with fat suppression showed mildlyperipheral internalenhancement,but these postcontrast sequences were not sufficiently reliable to interpret due cyst hyperintensities in T1.DWI: increased DWI signal, with lower ADC values in oval central zone- MRI finding was suspected of malignancy- cystic renal carcinoma. (Figure 5. and Figure 6.) 


\section{CASE REPORTS}

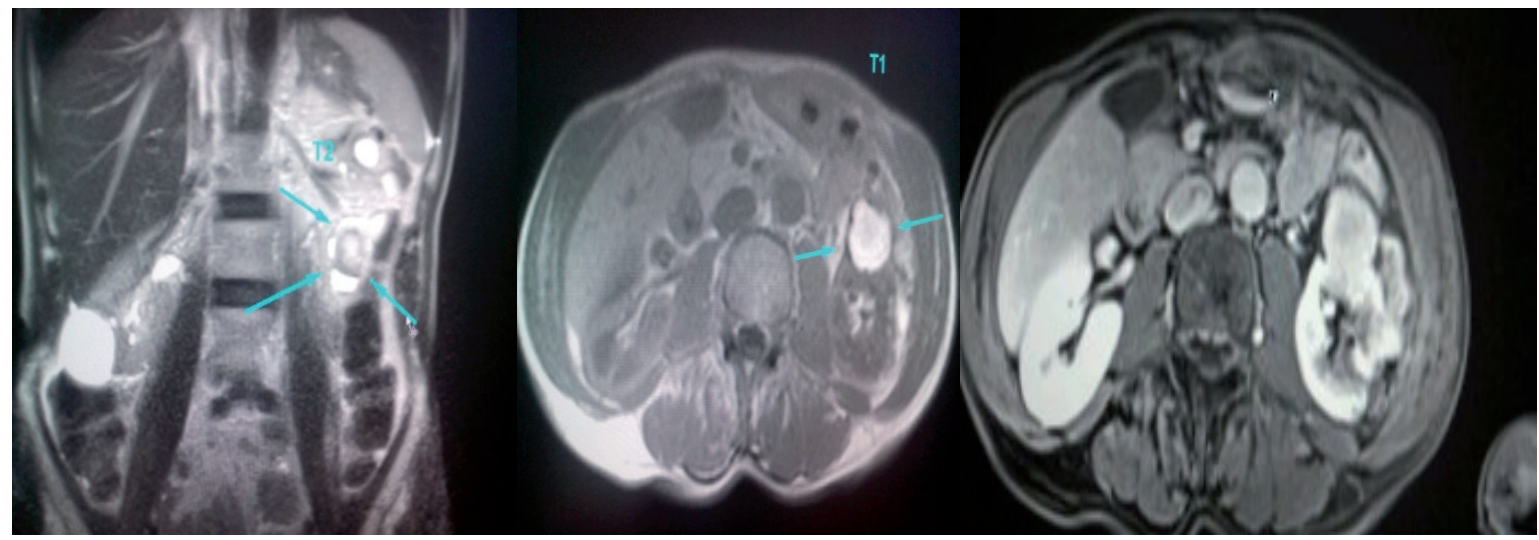

Figure 5. MRI T2WFS oblique, T1W axial native and T1W axial postcontrast sequences
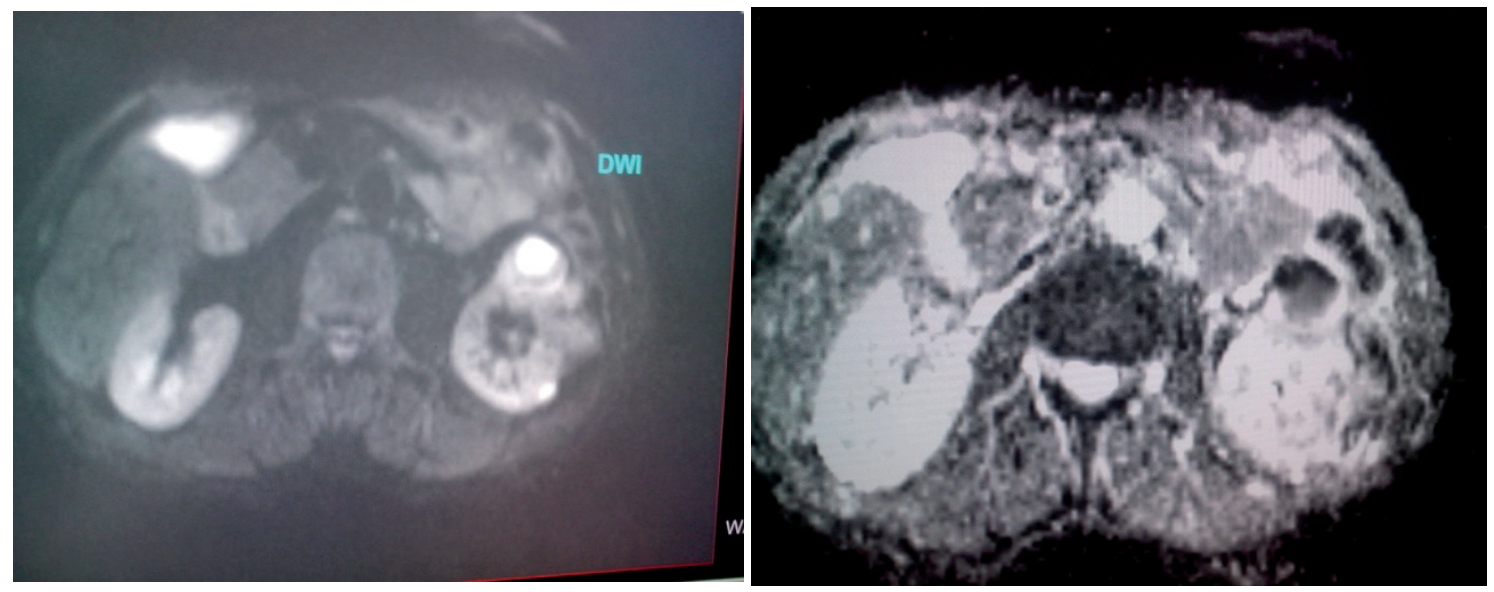

Figure 6. MRI: Increased DWI signal, with lower ADC values in oval central zone- MRI finding was suspected of malignancy- cystic renal cell carcinoma.

On consulting with the urosurgery department, the patient was posted for explorative surgery. Intra-op, the cyst was found to be with hemorrhagic content without a sign of infiltrative mass, but exploration was very difficult due to presence of adhesion owing to chronic pyelonephritis. Because of these circumstances left radical nephrectomy was done. Histopathological examination of the cystic lesion revealed hemorrhagic cyst with mild inflammation, polycystic kidneys and exacerbating chronic pyelonephritis.

\section{Discusion}

The differentiation between a benign renal cyst and a cystic RCC remains one of the more common and difficult problems in renal imaging. When a complex renal cyst is identified, determination of its benign or malignant nature is based on:

1.Evaluation of the wall of the lesion; its thickness and contour

2.The number, contour, and thickness of any septa

3.The amount, character, and location of any calcifications

4.The density of fluid in the lesion

5.The presence of solid components ${ }^{7}$ 
Historically renal cystic masses stratified into two broad groups; types I and II are nonsurgical lesions and types III and IV are typically resected surgically ${ }^{2}$. There is increasing risk of malignancy from type I (virtually $0 \%$ ) to type IV (near 100\%). Resection of type IV lesions is indicated due to the high risk of malignancy $5,6,7$. Type III lesions are indeterminate and cannot be definitely diagnosed as benign on imaging alone. Although the risk of malignancy is highly variable $(31-100 \%)^{8}$, resection is advocated so as not to miss a cancer. Biopsy in this group has been traditionally seen to be of limited use as false negative biopsy results are common ${ }^{9}$. Indeed, examination of the entire lesion at pathology is sometimes needed to render a histopathology diagnosis. However, some patients are not surgical candidates, and therefore biopsy may be useful.T2-weighted images are most helpful in distinguishing simple renal cysts from other lesions. A homogeneous hyperintense lesion with a thin wall on T2-weighted images can be accurately characterized as a simple cyst. Septa and solid nodules can be readily seen within cysts on T2-weighted images due to their relatively low signal intensity compared with the fluid contents within the cyst. Because of artifacts inherent to MR imaging, septa in renal cystic lesions may appear thicker than on $\mathrm{CT}^{1}$. This may lead to disagreements, and lesions classified as II or II-F on CT might be classified as II-F or III on MRI ${ }^{10}$. Complicated renal cysts with hemorrhagic or proteinaceous contents may have heterogeneous or low signal intensity on T2-weighted images, high signal on T1 weighted images, whereas solid tumors have variable signal intensity. In diffusionweighted MR imaging, the image contrast is influenced by the Brownian motion of water molecules. The signal intensity is high if water molecules are restricted in their motion, which can be caused by cell membranes or, in the case of free fluid, by high viscosity. The MR signal intensity is low if water molecules can diffuse freely. Because diffusion-weighted images are inherently T2-weighted, the images are influenced by the T2-shine-through effect. This is the presence of high signal intensity in restricted water, caused by the T2 effect. To cope with this effect, the apparent diffusion coefficient (ADC) may be calculated from two images acquired with different gradient duration and amplitude (b-values) and used for ADC mapping ${ }^{11}$.

Some authors wanted to determine the accuracy of apparent diffusion coefficient (ADC) measured with diffusion-weighted imaging (DWI) for the differentiation between hemorrhagic/proteinaceous cysts and T1hyperintense neoplasms and concludedthat malignant lesions have significantly lower ADC values as indicating more restricted diffusion, when compared to hemorrhagic/proteinaceous cysts ${ }^{12}$, but some authors concluded DW imaging can be used to characterize renal lesions; however, compared with CE MR imaging, it is less accurate ${ }^{11}$.

Multiple factors are likely to contribute to the overall signal intensity in hemorrhagic cyst. Such factors may include serum hematocrit and protein levels, stage of clot retraction, concentration of oxidized iron (Fe3) in hemoglobin,inflammation factors and corn- position of cyst fluid (e.g., osmolarity, water content, protein content, and cholesterol content). This is the most common cause that benign hemorrhagic, inflamed or proteinaceous cyst can mimicking malignant neoplasm ${ }^{13}$. Correlations among MRI, DWI, ADC, MR spectroscopy, and chemical analysis may provide insight into the characterization of cyst fluid.

\section{Conclusion}

Renal cysts can have distinct features at MR imaging. Recognition of some of these features may allow characterization of common and uncommon renal cystic lesion. MR imaging can be used to facilitate clinical management in patients with renal cysts by depicting certain lesions that do not require treatment, providing a safe method for longitudinal follow-up, and suggesting specific surgical approaches. But, atypical cysts can match a complicated cyst (infection, bleeding) or a cystic tumor. Radiological examination is often not enough for a clear differentiation, false negative biopsy results in this group are common and it may be necessary to perform a surgical treatment for an accurate diagnosis. 


\section{Literature}

1. Muglia VF, Westphalen AC. Bosniak classification for complex renal cysts: history and critical analysis. Radiol Bras. 2014;47(6):368-73.

2. Bosniak MA. The current radiological approach to renal cysts. Radiology. 1986;158(1):1-10.

3. Israel GM, Bosniak MA, Bosniak MA, Curry NS, Cochran ST, Bissada NK, et al. An update of the Bosniak renal cyst classification system. Urology. 2005;66(3):484-8.

4. Israel GM, Bosniak MA. How I Do It: Evaluating Renal Masses. Radiology 2005;236(2):441-50.

5. Wilson TE, Doelle EA, Cohan RH, Wojno K, Korobkin M. Cystic renal masses: a reevaluation of the usefulness of the Bosniak classification system. Acad Radiol . 1996;3(7):564-70.

6. Curry NS, Cochran ST, Bissada NK. Cystic Renal Masses. Am J Roentgenol. 2000;175(2):339-42.

7. Cloix P, Martin X, Pangaud C, Marechal J-M, Bouvier R, Barat D, et al. Surgical Management of Complex Renal Cysts: A Series of 32 Cases. J Urol. 1996;156(1):28-30.

8. Katabathina VS, Kota G, Dasyam AK, Shanbhogue AKP, Prasad SR. Adult Renal Cystic Disease: A Genetic, Biological, and Developmental Primer. RadioGraphics. 2010;30(6):1509-23.

9. Lang EK, Macchia RJ, Gayle B, Richter F, Watson RA, Thomas R, et al. CT-guided biopsy of indeterminate renal cystic masses (Bosniak 3 and 2F): accuracy and impact on clinical management. Eur Radiol. 2002;12(10):2518-24.

10. Weibl P, Klatte T, Kollarik B, Waldert M, Schüller G, Geryk B, et al. Interpersonal variability and present diagnostic dilemmas in Bosniak classification system. Scand J Urol Nephrol. 2011;45(4):239-44.

11. Taouli B, Thakur RK, Mannelli L, Babb JS, Kim S, Hecht EM, et al. Renal Lesions: Characterization with Diffusionweighted Imaging versus Contrast-enhanced MR Imaging. Radiology. 2009;251(2):398-407.

12. Kim S, Jain M, Hecht E, Lee V, Taouli B. Characterization of T1 hyperintense renal lesions with diffusion-weighted imaging: preliminary experience. Proc. Intl. Soc. Mag. Reson. Med. 2007;15: 2736

13. Fujii Y, Higashi Y, Owada F, Arisawa C, Horiuchi S. [Benign hemorrhagic renal cyst mimicking cystic renal cell carcinoma]. Hinyokika Kiyo. 1993;39(12):1113-7.

Corresponding author:

Natasa Rakonjac

Clinical Hospital Center Zemun, Belgrade

Tel. 0113772629

Mob. 0641950350

E mail: natasarakonjac@yahoo.com 